\title{
Determination of The Hygienic Quality of Tap Waters of Afyonkarahisar Province
}

\author{
Gökhan AKARCA ${ }^{*}$, Oktay TOMAR², Ömer İSTEK¹ \\ ${ }^{1}$ Afyon Kocatepe University, Faculty of Engineering, Department of Food Engineering, 03200, Afyonkarabisar, Turkey \\ ${ }^{2}$ Kocaeli University, Faculty of Agriculture and Natural Science, Arslanbey Campus, 41285, Kocaeli, Turkey
}

\begin{abstract}
In this study, the microbiological and chemical properties of drinking water taken from fountains in the city center of Afyonkarahisar province were investigated. As a result, Escherichia coli was detected in $9(22.5 \%)$ of forty samples examined. In 19 (47.5\%) of them, it was determined that coliform group bacteria were above the values specified in the statute. It was determined that the total aerobic mesophilic bacteria count was $0-3.45 \mathrm{cfu}$ $\mathrm{kob} / 250 \mathrm{ml}$, the coliform group bacteria count was $0-2.59 \mathrm{cfu} \mathrm{kob} / 250 \mathrm{ml}$, the psychrophilic group bacteria count was $0.48-2.81 \log \mathrm{cfu} / 250 \mathrm{ml}$, and the Escherichia coli count was $0-1.97 \log \mathrm{cfu} / 250 \mathrm{ml}$. In chemical analyses, $\mathrm{pH}$, conductivity, hardness, nitrite, ammonium, bicarbonate, clarity, fluorine, chlorine values were determined to be $7.46,344.4,16.03,0.061,0.0312,151.39,9.8,0.144,0.171 \mathrm{mg} / \mathrm{mL}$, respectively, on average. Although the chemical results indicated in samples were found appropriate according to the regulation on water for human consumption, in microbiological results, all samples did not comply with the quality criteria specified in the regulation on water for human consumption in terms of Escherichia coli, coliform, TAMB, total psychrophilic aerobic bacteria. In conclusion, it was concluded that the hygienic quality of drinking and tap water in the city center of Afyonkarahisar did not comply with the regulation on water for human consumption and had significant risks for public health.
\end{abstract}

Keywords: Afyonkarahisar, tap water, hygienic quality, microbiological.

\section{Afyonkarahisar İli Çeşme Sularının Hijyenik Kalitesinin Belirlenmesi}

ÖZ

Bu çalışmada Afyonkarahisar ili şehir merkezinde bulunan çeşmelerden alınan içme sularının mikrobiyolojik ve kimyasal özellikleri araştırılmıştır. Sonuç olarak; incelenmesi yapılan kırk örneğin 9 adedinde (\%22.5) Escherichia coli tespit edilmiştir. 19 adedinde (\%47.5) ise; Koliform grubu bakterileri tüzükte belirtilen değerlerin üzerine olduğu saptanmıştır. Toplam aerobik mezofilik bakteri sayısı 0-3.45 log kob/250ml, koliform grubu bakteri sayıs1 0-2.59 $\log \mathrm{kob} / 250 \mathrm{ml}$, psikrofil bakteri grubu sayıs1 0.48-2.81 log kob/250ml, Escherichia coli sayıs1 0-1.97 log kob/250ml aralığında olduğu tespit edilmiştir. Kimyasal analizlerde $\mathrm{pH}$, iletkenlik, sertlik, nitrit, amonyum, bikarbonat, berraklık, flor, klor değerleri sirasiyla ortalama 7.46, 344.4, 16.03, 0.061, 0.0312, 151.39, 9.8, 0.144, $0.171 \mathrm{mg} / \mathrm{mL}$ olarak saptanmıştır. Örneklerde belirtilen kimyasal sonuçlar İnsani tüketim amaçlı sular yönetmeliğine göre uygun bulunmasına karşın mikrobiyolojik sonuçlarda tüm numuneler Escherichia coli, koliform, TAMB, toplam psikrofil aerobik bakteri yönünden insani tüketim amaçlı sular yönetmeliğinde belirtilen kalite kriterlerine uygunluk göstermemektedir. Sonuç olarak, Afyonkarahisar şehir merkezindeki içme ve kullanma sularının hijyenik kalitesinin insani tüketim amaçlı sular yönetmeliğe uymadığı ve halk sağlı̆ı açısından önemli riskler taşıdığı kanaatine varılmıştır.

Anahtar Kelimeler: Afyonkarahisar, çeşme suyu, hijyenik kalite, mikrobiyoloji.

To cite this article: Akarca G. Tomar O. İstek Ö. Determination of The Hygienic Quality of Tap Waters of Afyonkarabisar Province. Kocatepe Vet J. (2020) 13(2):125-129 


\section{INTRODUCTION}

Water is consumed as an indispensable natural resource for the continuation of future generations and the ecosystem. Although people can continue their vitality activities for days and weeks without food intake, they can only live a few days in case of any drought (Uzundumlu et al. 2016). Human beings, who perceived the importance of this situation, always preferred to be close to water resources while establishing their settlements (Demirel 2009, Hare 2014). Furthermore, people need to consume the same amount of water as the daily energy taken to be able to maintain their lives in a healthy way (Sciamanna et al. 2011, Drewnowski et al. 2013, Muckelbauer 2013).

Although three-quarters of the world's surface are covered with water, only $2.6 \%$ of the water reserve consists of freshwater (Miller 2004). Water is not only home to living creatures but also constitutes the main source of vitality. Water, which may be present in different types of cells and tissues at different ratios, constitutes $65-70 \%$ of the human body (Erk 2016).

Multiple factors such as population growth, industrialization, and consequently energy need of countries may be effective on water consumption. In addition to the amount of consumption, the fact that water reaches consumers hygienically becomes even more important with each passing day. More technology has been used to meet the needs of the rapidly growing population in recent years. Therefore, access to clean and natural water resources becomes difficult over time since people use natural resources wastefully (Varer 2010).

The fact that the bacteriological, chemical, physical, and ecological properties of water resources are negatively affected, and the discharging of substances or wastes that will directly or indirectly cause preventive deteriorations in human health and water quality lead to water pollution (Tosunoglu et al. 1999). In the world, 250 million people contract waterborne epidemics every year, and it is reported that approximately 10 million of them die of microbial infections. In its report entitled "water quality and health strategy" covering the period between 2013 and 2020, the World Health Organization (WHO) reported that 589.854 waterborne infection cases were reported from 58 world countries and there was an $85 \%$ increase in waterborne infections compared to 2010 (Rifaat et al. 2014).

Contaminated water directly or indirectly constitutes a risk to public health. It was indicated that the consumption of vegetables and fruits washed with contaminated water, the consumption of fish caught in contaminated water or the consumption of this water may lead to many infections or toxications caused by pathogenic bacteria (Erkan and Vural 2006).

Coliform groups are the most problematic group of bacteria in drinking water in terms of health. Coliform group bacteria are divided into two groups according to their characteristic features. Fecal coliform bacteria and Escherichia coli are considered to be the indicators of fecal contamination in water. Pathogenic types of Escherichia coli may cause diarrhea, meningitis, septicemia, arteriosclerosis, Hemolytic Uremic Syndrome (HUS), and various immunological diseases leading to death in living creatures (Rifaat et al. 2014).

In this study, it was aimed to investigate tap waters in Afyonkarahisar and its vicinity from physical, chemical, microbiological aspects and to determine a risk they pose to human health.

\section{MATERIAL and METHODS}

\section{Materials}

40 samples were taken from the fountains in the city center of Afyonkarahisar province into previously sterilized jars under suitable conditions in accordance with the hygiene rules. The samples were brought to the Food Engineering Laboratory of Afyon Kocatepe University Faculty of Engineering under suitable conditions and analyzed.

\section{Microbiological Analyses}

Escherichia coli, total psychrophilic aerobic bacteria group, total aerobic mesophilic bacteria (TAMB), and total coliform analyses were performed in the samples taken.

\section{Preparation of samples for microbiological analyses}

Before the analysis, the materials to be used were passed through alcohol, and this alcohol was removed with burner flame and sterilized. The working environment was also ensured to be sterile. This process was repeated for each sample to be analyzed.

\section{Escherichia coli analysis}

$250 \mathrm{~mL}$ of the water sample taken was passed through a sterilized membrane filtration system. Then, the membrane filters were placed on the Petri plate with sterile forceps so that no air remained. Attention was paid to ensure that the bacterial surface was at the top while placing the filter on the VRB agar medium. The lid of the Petri plate was allowed to incubate at $37{ }^{\circ} \mathrm{C}$ for $24-48$ hours on the top. After incubation, microorganism count was performed directly. The colonies that gave bright pink color were considered Escherichia coli and calculated logarithmically (Ekici et al. 2010). 
Total aerobic mesophilic bacteria analysis

$250 \mathrm{~mL}$ of the water sample taken was passed through a sterilized membrane filtration system. Then, the membrane filters were placed on the Petri plate with sterile forceps so that no air remained. Attention was paid to ensure that the bacterial surface was at the top while placing the filter on the Lactose TTC agar medium. The lid of the Petri plate was allowed to incubate at $37^{\circ} \mathrm{C}$ for $24-48$ hours on the top. After incubation, microorganism count was performed directly and calculated logarithmically (Ekici et al. 2010).

\section{Total coliform bacteria analysis}

$250 \mathrm{~mL}$ of the water sample taken was passed through a sterilized membrane filtration system. Then, the membrane filters were placed on the Petri plate with sterile forceps so that no air remained. Attention was paid to ensure that the bacterial surface was at the top while placing the filter on the VRB agar medium. The lid of the Petri plate was allowed to incubate at $37^{\circ} \mathrm{C}$ for $24-48$ hours on the top. After incubation, microorganism count was performed directly. The colonies that gave metallic luster were considered coliform and calculated logarithmically (Ekici et al. 2010).

\section{Total psychrophilic aerobic bacteria analysis}

$250 \mathrm{~mL}$ of the water sample taken was passed through a sterilized membrane filtration system. Then, the membrane filters were placed on the Petri plate with sterile forceps so that no air remained. Attention was paid to ensure that the bacterial surface was at the top while placing the filter on the Lactose TTC agar medium. The lid of the Petri plate was allowed to incubate at $4{ }^{\circ} \mathrm{C}$ for 3-4 days on the top. After incubation, microorganism count was performed directly and calculated logarithmically (Ekici et al. 2010).

\section{Chemical analyses $\mathrm{pH}$ analysis}

A $\mathrm{pH}$ meter was standardized by buffer solutions with constant $\mathrm{pH}$ value. Thus, the error level was minimized. After the $\mathrm{pH}$ meter was standardized, the $\mathrm{pH}$ value of each sample was measured. $\mathrm{pH}$ and conductivity were measured using the $\mathrm{pH}$ meter (Hanna HI 2215) (Akarca et al. 2015).

\section{Hardness analysis}

After $25 \mathrm{ml}$ of the test sample was taken and completed to $50 \mathrm{ml}, 1-2$ drops of buffer solution were added. Very little powder indicator solution was added with a spatula tip. It was titrated with $0.01 \mathrm{M}$ EDTA solution until the color changed from wine red to blue. Then, the volume spent was recorded. This volume gives us information about the hardness of the sample (Yelekci 2014).

\section{Analysis of free ion amount}

While the amount of chloride (CI- $\mathrm{mg} / \mathrm{L}$ ) ion was analyzed using the Merck Nova 60-14897 kit by the spectrophotometric method, Nitrite nitrogen $\left(\mathrm{NO}_{2}-\mathrm{N}\right.$ $\mathrm{mg} / \mathrm{L}$ ) was analyzed using the Merck Nova 14776 kit by the spectrophotometric method, Ammonium nitrogen $\left(\mathrm{NH}_{4}-\mathrm{N} \mathrm{mg} / \mathrm{L}\right)$ was analyzed using the Merck Nova 60-14752 kit by the spectrophotometric method, and Fluoride ( $\left.\mathrm{F}^{-} \mathrm{mg} / \mathrm{L}\right)$ was analyzed using the Merck Nova 60-14598 kit by the spectrophotometric method (Kalyoncu and Zeybek 2009).

\section{Clarity and bicarbonate amount analysis}

Clarity and bicarbonate were analyzed by spectrophotometric methods (Kalyoncu and Zeybek 2009).

\section{RESULTS and DISCUSSION}

\section{Results of microbiological analysis}

The microbiological values of drinking water of Afyonkarahisar province were determined and presented in Table 1.

\section{Results of chemical analysis}

With respect to the chemical analysis of drinking water of Afyonkarahisar province, $\mathrm{pH}$, conductivity, hardness, nitrite, ammonium, bicarbonate, clarity, fluorine, and chlorine analyses were performed. The results of these chemical analyses are presented in Table 2.

In this study, Escherichia coli was detected in 9 of the forty samples investigated. Coliform group bacteria in $19(47.5 \%)$ of them were found to be above the values specified in the statutes. It was determined that the count of Escherichia coli varied between 0-1.97 log $\mathrm{cfu} / 250 \mathrm{ml}$, the coliform group bacteria count varied between 0-2.59 log cfu $/ 250 \mathrm{ml}$, TAMB count varied between 0-3.45 $\log \mathrm{cfu} / 250 \mathrm{ml}$, and the psychrophilic bacteria group count varied between 0.48-2.81 log $\mathrm{cfu} / 250 \mathrm{ml}$. Analysis results are presented in Table 1.

As a result of chemical analyses, it was found that the average value of $\mathrm{pH}$ (40 samples) was 7.46, the average value of conductivity (40 samples) was 344.4 $(\mu \mathrm{S} / \mathrm{cm})$, the average value of hardness (40 samples) was $16.03(\mathrm{mg} / \mathrm{L})$, the average value of nitrite $(40$ samples) was $0.061(\mathrm{mg} / \mathrm{L})$, the average value of ammonium (40 samples) was $0.031(\mathrm{mg} / \mathrm{L})$, the average value of bicarbonate (40 samples) was 151.39 $(\mathrm{mg} / \mathrm{L})$, the average value of clarity (40 samples) was $9.8(\mathrm{mg} / \mathrm{L})$, the average value of fluorine (40 samples) was $0.144(\mathrm{mg} / \mathrm{L})$, and the average value of chlorine (40 samples) was $0.171(\mathrm{mg} / \mathrm{L})$. Analysis results are presented in Table 2. 
In a study carried out by Anar and Gunsen (2000) on 100 samples in the city center of Bursa province, while coliform group bacteria were found microbiologically in $7 \%$ of the samples, $0.78 \%$ of them were found to have more than 500 aerobic bacteria. In the study carried out by Alemdar et al. (2009) on drinking water in Bitlis province, it was determined that $7 \%$ had coliform, $7 \%$ had E. coli, $66 \%$ had TAMB, and 54\% had psychrophilic microorganisms. It was determined that the results obtained in those studies were in parallel with the results of our study. It is foreseen that very dangerous epidemic cases may occur if the quality of drinking water cannot be controlled.

In a study carried out by Duressa et al. (2019), 30 drinking water samples were taken from three different points (main distribution tank, disinfection point, and home taps) in Ethiopia. Chemical and microbiological analyses were performed on those samples. Based on the data obtained, it was determined that temperature varied between 16.9-22 ${ }^{\circ} \mathrm{C}$ and clarity varied between $6.8-7.0 \mathrm{mg} / \mathrm{L}$. It was also determined that total dissolved matter and electrical conductivity varied between $50-70 \mathrm{mg} / \mathrm{L}$ and 40-46 $\mu \mathrm{S} / \mathrm{cm}$, respectively. Phosphate and nitrate concentrations in water samples varied between 0.65 $1.00 \mathrm{mg} / \mathrm{L}$ and $2.2-6.5 \mathrm{mg} / \mathrm{L}$, respectively. It was determined that the concentration of chlorine released in most of our water samples was less than $0.5 \mathrm{mg} / \mathrm{L}$. Total coliform positive bacteria ranging from 1.08-2.08 $\log \mathrm{cfu} / 100 \mathrm{ml}$ were found in all samples. Fecal coliform was found in $37 \%$ of tap water. It indicates that this study was parallel to our study and microbiological pollution of drinking water had a significant effect on water quality.

In this study, microbiological and chemical analyses were performed on the hygienic quality of drinking water in Afyonkarahisar. In microbiological analyses, it was found that Escherichia coli was positive in 9 $(22.5 \%)$ of them, Coliform group bacteria were positive in $19(47.5 \%)$ of them, Total aerobic mesophilic bacteria (TAMB) were positive in 40 $(100 \%)$ of them, and Total Psychrophilic Aerobic Bacteria group was positive in $40(100 \%)$ of them. In chemical analyses, $\mathrm{pH}$, conductivity, hardness, nitrite, ammonium, bicarbonate, clarity, fluorine, chlorine values were found to be $7.46,344.4,16.03,0.061$, $0.0312,151.39,9.8,0.144$, and $0.171 \mathrm{mg} / \mathrm{mL}$, respectively.

Table 1. Microbiological values of tap waters in Afyonkarahisar province (log cfu/250ml).

\begin{tabular}{lccc}
\hline Bacteria & $\begin{array}{c}\text { Average Value } \\
(\mathbf{n}=\mathbf{4 0})\end{array}$ & $\begin{array}{c}\text { Minimum Value } \\
(\mathbf{n}=\mathbf{4 0})\end{array}$ & $\begin{array}{c}\text { Maximum Value } \\
(\mathbf{n}=\mathbf{4 0})\end{array}$ \\
\hline Escherichia coli & 0.98 & 0 & 1.97 \\
Coliform & 1.29 & 0 & 2.59 \\
TAMB Count & 1.73 & 0 & 3.45 \\
Psychrophilic & 1.65 & 0.48 & 2.81 \\
\hline
\end{tabular}

Table 2. Chemical analysis values of tap waters from Afyonkarahisar province.

\begin{tabular}{lccc}
\hline Chemical Analysis & $\begin{array}{c}\text { Average Value } \\
(\mathbf{n = 4 0 )}\end{array}$ & $\begin{array}{c}\text { Minimum Value } \\
(\mathbf{n = 4 0 )}\end{array}$ & $\begin{array}{c}\text { Maximum Value } \\
(\mathbf{n}=\mathbf{4 0})\end{array}$ \\
\hline $\mathrm{pH}$ & 7.46 & 6.54 & 7.71 \\
Conductivity $(\mu \mathrm{S} / \mathrm{cm})$ & 344.4 & 181.45 & 437 \\
Hardness $(\mathrm{mg} / \mathrm{L})$ & 16.03 & 7.7 & 19.11 \\
Nitrite $(\mathrm{mg} / \mathrm{L})$ & 0.061 & 0.008 & 0.102 \\
Ammonio $(\mathrm{mg} / \mathrm{L})$ & 0.0312 & 0.015 & 0.110 \\
Bicarbonate $(\mathrm{mg} / \mathrm{L})$ & 151.39 & 24.3 & 196.75 \\
Clarity $(\mathrm{mg} / \mathrm{L})$ & 9.8 & 0 & 30.5 \\
Fluorine $(\mathrm{mg} / \mathrm{L})$ & 0.144 & 0.01 & 0.645 \\
Chlorine $(\mathrm{mg} / \mathrm{L})$ & 0.171 & 0.05 & 0.255 \\
\hline
\end{tabular}

\section{CONCLUSION}

The values found as a result of chemical analysis complied with TS 266 and the regulation on water for human consumption. However, the values found as a result of microbiological analyses did not comply with TS 266 and the Regulation on Water for Human
Consumption (Akin and Akin 2007). The consumption of these waters endangers public health.

The prevention of microbiological pollution will be achieved by raising the awareness of public and the controlling of relevant institutions. 
When it is considered that our body needs to take 2.5 liters of water on average every day, the quality of drinking water is very important for our health. Nowadays, drinking water is exposed to many contaminations, especially originating from humans or animals. It is certain that drinking these waters polluted as a result of the contamination by intestinal bacteria such as Escherichia coli will bring along many outbreaks, as well.

When the relevant studies that have been carried out so far are considered, hygiene and sanitation processes of drinking-tap water should be conducted without delay. The improvement of the hygiene and sanitation conditions of water will prevent diarrheal diseases that are likely to occur depending on water consumption and the deaths related to these diseases and will decrease the incidence of other waterborne diseases.

Conflict of Interest: The authors declare that they have no conflict of interest.

\section{REFERENCES}

Akarca G, Kahraman A, Tomar O. Change of the shelf life of pasteurized milk which added in various amonds of cinnamon. Afyon Kocatepe University Journal of Sciences and Engineering, 2015; 15: 1-9.

Akin M, Akin G. Importance of water, water potential in Turkey, water basins and water pollution. Ankara University the Journal of the Faculty of Languages and History-Geography, 2007; 47(2): 105-118.

Alemdar S, Kahraman T, Agaoglu S, Alisarli M. Some microbiological and physicochemical properties of drinking water in Bitlis district. Ekoloji Journal, 2009; 19(73): 29-38

Anar S, Gunsen U. The hygienic quality of drinking and usage water in Bursa. Medical Journal of Süleyman Demirel University, 2000; 7: 31-34.

Demirel M. Policies and problems in water resources management: an assesment in Denizli sample. MSc Thesis, Pamukkale University, Denizli, Turkey, 2009.

Drewnowski A, Colin DR, Florence C. Water and beverage consumption among adults in the united states: crosssectional study using data from NHANES 2005-2010. BMC Public Health, 2013; 13: 1068.

Duressa G, Assefa F, Jida M. Assessment of bacteriological and physicochemical quality of drinking water from source to household tap connection in Nekemte, Oromia, Ethiopia. Hindawi Journal of Environmental and Public Health, 2019; 7 page.

Ekici K, Korkoca H, Sancak YC, Atalan E. The determination coliforms and E. coli in drinking water of Van and province. Uludag University Journal of the Faculty of Veterinary Medicine, 2010; 29(2): 21-25.

Erk I. Experimental and theoretical investigation of tissue equivalency for phantom materials. MSc Thesis, Istanbul Technical University, Istanbul, Turkey, 2016.

Erkan ME, Vural A. A study about of hygienic quality of Dicle (Tigris) river. Dicle Medical Journal, 2006; 33(4): 205-209.
Hare KE. Water supply assessment in Kilifi county. PhD Thesis, University of Nairobi, Nairobi, Kenya, 2014.

Kalyoncu H, Zeybek M. Benthic fauna of Ağlasun and Isparta streams and determination of water quality. Research Journal of Biological Science, 2009; 2(1): 41-48.

Miller GT. Sustaining the Earth, 6th edition. Thompson Learning, Inc. Pacific Grove, 211-216. California, USA, 2004.

Muckelbauer R, Sarganas G, Gruneis A, Muller-Nordhorn J. Association between water consumption and body weight outcomes: A systematic review. The American Journal of Clinical Nutrition, 2013; 98(2): 282-299.

Rifaat EA, Tekiner IH, Ozpinar H. Classical and MASS spectrometer examination of the existence of coliform and fecal coliform bacteria in drinking and use waters for public health. Electronic Journal of Food Technologies, 2014; 9(2): 20-32.

Sciamanna CN, Kiernan M, Rolls BJ, Boan J, Stuckey H, Kephart D, Miller CK, Jensen G, Hartmann TJ, Loken E. Practices associated with weight loss versus weight-loss maintenance results of a national survey. American Journal of Preventive Medicine, 2011; 41: 159166.

Tosunoglu V, Boncukoglu R, Anapali O, Sahin U. Contamination of Karasu river by city and industrial wastes. Atatürk University Journal of the Faculty of Agricultural, 1999; 30(2): 169-176.

Uzundumlu AS, Fakioglu O, Kokturk M, Temel T. Determining of the best drinking water preference in Erzurum province. Alinteri Journal of Agriculture Science, 2016; 30(1): 1-7.

Varer KV. Microbiological Quality Analysis's Parameter of Bottled Water Being Sold in Trabzon. MSc Thesis, Karadeniz Technical University, Trabzon, Turkey, 2010.

Yelekci S, Acemioglu B, Avci H. Investigation of the usability of the drinking water of Kilis province. Research Journal of Biological Science, 2014; 5(2): 77-81. 